\title{
ACTIVIDAD DEL TRIBUNAL CONSTITUCIONAL: RELACIÓN DE SENTENCIAS DICTADAS DURANTE EL TERCER CUATRIMESTRE DE 2019
}

\section{Activity of the Constitutional Court: List of rulings handed down during the third four-month period of 2019}

\author{
ÁREA DE DERECHO CONSTITUCIONAL \\ Universidad Carlos III de Madrid' \\ aelvira@der-pu.uc3m.es
}

Cómo citar/Citation

Elvira Perales, A. y Espinosa Díaz, A. (coords.) (2020)

Actividad del Tribunal Constitucional: relación de sentencias dictadas

durante el tercer cuatrimestre de 2019

Revista Española de Derecho Constitucional, 118, 193-218

doi: https://doi.org/10.18042/cepc/redc.118.07

Las sentencias dictadas en el segundo cuatrimestre del año se desglosan de la siguiente forma:

A) Las sentencias dictadas en recursos de inconstitucionalidad han sido diez.

La Sentencia (en adelante STC) 105/2019, de 19 de septiembre, resuelve el recurso interpuesto por más de cincuenta diputados del Grupo Parlamentario Popular del Congreso en relación con diversos preceptos de la Ley 21/2018, de 16 de octubre, de mancomunidades de la Comunidad Valenciana. El Tribunal concluye que el art. 36.8 de la Ley 21/2018 no vulnera la autonomía provincial al interpretar que "[l]a prioridad a la que alude ha de

1 La presente relación de sentencias ha sido elaborada por los profesores Elvira Perales y Espinosa Díaz (coords.), Gómez Lugo, Baamonde Gómez y López Rubio. 
entenderse en el sentido de que no permite excluir la colaboración con otros entes locales, ha de referirse a las actividades y servicios a las que alude el art. $12.2 \mathrm{~d}$ ) y debe ser concretada por la diputación provincial en la forma que estime oportuna» (FJ 6 e). Tampoco considera inconstitucional el art. 50.4 de la misma Ley 21/2018, en la medida en que dicho precepto se refiere a todas las mancomunidades y no solo a las de ámbito comarcal, de modo que, a su juicio:

[El] concreto alcance de esta previsión ha de fijarlo la propia diputación en el marco de libre decisión que implica el diseńo de los correspondientes planes de cooperación. Esto es, la decisión última compete a la diputación provincial, a la que corresponde determinar el modo en que incorpora el criterio de prioridad que recoge el precepto impugnado a la hora de valorar las obras y servicios a financiar, de suerte que podrá también concretar cómo pondera cada uno de los proyectos de inversión y, lógicamente, podrá adicionar otros. Entendido en tales términos, que se llevarán al fallo, el art. 50.4 no es inconstitucional (FJ 7 c).

La STC 113/2019, de 3 de octubre, resuelve el recurso interpuesto por el presidente del Gobierno respecto de los apartados tercero y sexto del artículo único de la Ley $9 / 2018$, de 31 de julio, por la que se modifica la Ley 12/2016, de 17 de agosto, de evaluación ambiental de las Illes Balears. El Tribunal delimita el reparto de competencias en materia de evaluación ambiental y trae a colación lo decidido en los FF. JJ. 7 a 9 de la STC 13/1988 para examinar el alcance del ejercicio de las competencias autonómicas, y su afectación transversal sobre las competencias sectoriales estatales al someter a evaluación ambiental a proyectos, planes y programas del Estado. De este modo, concluye declarando la inconstitucionalidad de:

[...] la mención contenida en el apartado primero del art. 9 de la Ley 12/2016 tras la reforma realizada por el artículo único. 3 de la Ley 9/2018 «del Consejo de Ministros» y que se interprete que la referencia a la «administración pública» como administración autonómica, insular o local de las Illes Balears no comprende a la Administración General del Estado. En tanto que los apartados segundo, tercero y cuarto aparecen redactados mediante la técnica de remisión directa o indirecta al apartado primero, la inconstitucionalidad de los mismos queda resuelta por el pronunciamiento efectuado en relación con el apartado primero del art. 9 (FJ 5).

La STC 116/2019, de 16 de octubre, resuelve el recurso interpuesto por más de cincuenta diputados del Grupo Parlamentario Popular en el Congreso 
de los Diputados respecto del art. 50 de la Ley del Parlamento de las Illes Balears 13/2018, de 28 de diciembre, de caminos públicos y rutas senderistas de Mallorca y Menorca. En ella se considera que:

[...] el legislador balear dispone una serie de finalidades legítimas en el seno de políticas sectoriales de su competencia, expresivas de unos intereses sociales fijados en abstracto, que justifican que, para su consecución y en los términos previstos en la norma, se haga uso de la potestad expropiatoria. Por ello, el Tribunal aprecia que, a la vista de los objetivos perseguidos por la Ley autonómica 13/2018, concurre la finalidad de utilidad pública o interés social que ha de legitimar cualquier medida de naturaleza expropiatoria (FJ 4 b).

La argumentación del Tribunal conduce a un fallo de carácter desestimatorio.

La STC 127/2019, de 31 de octubre, resuelve el recurso interpuesto por más de cincuenta diputados, integrantes del Grupo Parlamentario confederal de Unidos Podemos-En Comú y Podem-En Marea en relación con diversos preceptos de la Ley 9/2018, de 26 de diciembre, de presupuestos generales de la Comunidad de Madrid para el año 2019. En ella se recurría por posible inconstitucionalidad la suspensión para el ejercicio 2019 de la vigencia y aplicación de cualquier previsión relativa a la percepción de beneficios sociales, gastos de acción social y de todos aquellos de naturaleza similar, tanto en metálico como en especie, que tuvieran su origen en acuerdos, pactos o convenios suscritos entre los entes integrantes del sector público de la Comunidad de Madrid y los representantes del personal a su servicio. Las CC. AA. deben respetar las medidas de contención del gasto del Estado, pero, además de estas, pueden establecer las que consideren necesarias. Haciendo referencia a jurisprudencia anterior, el Tribunal señala que no se da ninguna de las contradicciones señaladas por los recurrentes. Formula un voto particular concurrente del magistrado don Fernando Valdés.

La STC 132/2019, de 13 de noviembre, resuelve el recurso interpuesto por el presidente del Gobierno respecto de diversos preceptos de la Ley del Parlamento de Cataluña 3/2017, de 15 de febrero, del libro sexto del Código Civil de Cataluña, relativo a las obligaciones y los contratos, y de modificación de los libros primero, segundo, tercero, cuarto y quinto. En primer lugar, se declara constitucional lo relativo a los contratos de compraventa, permuta, mandato y gestión de negocios ajenos por entenderse incluidos dentro de la previsión del art. 149.1.8. ${ }^{\circ} \mathrm{CE}$, dado que siempre han existido estas figuras en el derecho civil catalán. En alguna de ellas existe cierta innovación, pero, conforme al precepto constitucional citado, la comunidad autónoma tenía 
competencia para ello. Por el contrario, declara inconstitucional el 621.54.3, pues contiene una norma procesal de resolución extrajudicial de conflictos y no puede incardinarse en la excepción prevista en el art, 149.1.6. ${ }^{\circ} \mathrm{CE}$, por lo que invade competencias estatales en materia procesal. Formulan votos particulares cinco magistrados. Don Andrés Ollero considera que se ha producido, sin advertirlo, un cambio en la jurisprudencia del Tribunal y que se hace una incorrecta reflexión de lo que debe entenderse por las «bases». Don Antonio Narváez discrepa ante la ausencia de reflexión en torno a la «materia mercantil» que también puede verse afectada por la legislación recurrida; por otro lado, considera que la sentencia supone reconocer una competencia casi ilimitada a Cataluña en materia civil. Don Alfredo Montoya mantiene, por su parte, argumentos similares a los de los votos anteriores. Don Ricardo Enríquez discrepa del concepto de "bases» utilizado en esta sentencia, así como de la metodología empleada para el examen de los preceptos impugnados.

La STC 133/2019, de 13 de noviembre, resuelve el recurso interpuesto por el Gobierno Vasco respecto de diversos preceptos de la Ley 6/2018, de 3 de julio, de presupuestos generales del Estado para el ańo 2018, y del Real Decreto Ley 28/2018, de 28 de diciembre, para la revalorización de las pensiones públicas y otras medidas urgentes en materia social, laboral y de empleo. El recurso es parcialmente estimado, de manera que, en relación con la «ayuda de acompañamiento para jóvenes inscritos en el sistema nacional de garantía juvenil que suscriban un contrato de formación y aprendizaje», el Tribunal considera que tal ayuda debe incardinarse dentro de la competencia del 149.1.13. ${ }^{\circ} \mathrm{CE}$ y, por tanto, que efectivamente se están invadiendo las competencias del País Vasco en la materia, puesto que no se han justificado circunstancias excepcionales que pudiesen justificar la gestión centralizada, por lo que se declaran inconstitucionales y nulos los apartados o incisos impugnados de la disposición adicional centésima vigésima LPGE. En relación con el segundo bloque de medidas recurridas, relativas a la gestión estatal del subsidio extraordinario de desempleo, el Tribunal declara que esta es una competencia estatal.

La STC 158/2019, de 12 de diciembre, resuelve el recurso interpuesto por más de cincuenta diputados del Grupo Parlamentario Popular del Congreso de los Diputados respecto de la Ley de las Cortes de Aragón 8/2018, de 28 de junio, de actualización de los derechos históricos de Aragón. Al entrar en el análisis de fondo, el Tribunal opta por considerar en primer lugar las tachas de inconstitucionalidad referidas a la totalidad de la ley. Así, el motivo de inconstitucionalidad imputado a la ley aragonesa por no respetar la disposición adicional primera CE es acogido por el Tribunal, si bien no afecta a la totalidad del texto. De ahí que solo determinados preceptos sean 
declarados inconstitucionales y nulos por esta razón: art. 1, apartados primero, segundo y tercero; arts. 2 a 5; art. 6 , apartado primero, inciso «como sucesores de las instituciones del antiguo Reino de Aragón»; art. 14, apartados primero, segundo y tercero; art. 15; art. 16, apartado tercero; art. 18, apartado primero, inciso "tiene su origen histórico en la Diputación del Reino"; art. 20; art. 21; art. 22; art. 25; art. 26, apartado primero; art. 32 a); disposición adicional segunda, apartado primero, párrafo primero, inciso «y sus derechos históricos»; disposición adicional tercera, y disposición final tercera. En relación con el art. 1.2. CE interpretado sistemáticamente con el art. $147 \mathrm{CE}$, se consideran, asimismo, inconstitucionales y nulos: art. 9; art. 10, apartado primero y art. 11, apartado primero. Entrando en las impugnaciones específicas, se declaran inconstitucionales: el inciso «al asilo» del art. 6.3; art. 7, apartado primero c); art. 8, apartado b); art. 10.2; art. 26, apartados segundo y tercero; art. 31; art. 33, apartados tercero y quinto, y, sin perjuicio de la salvedad hecha del inciso "y sus derechos históricos», el párrafo primero del apartado primero de la disposición adicional segunda no es inconstitucional, siempre que se interprete en los términos establecidos en el fundamento jurídico $8 \mathrm{j}$ ), siendo inconstitucional su apartado segundo.

La STC 161/2019, de 12 de diciembre, resuelve el recurso interpuesto por más de cincuenta diputados del Grupo Parlamentario confederal de Unidos Podemos-En Comú y Podem-En Marea, respecto de la Ley de la Asamblea Regional de Murcia 10/2018, de 9 de noviembre, de aceleración de la transformación del modelo económico regional para la generación de empleo estable de calidad. La alegación de inconstitucionalidad formulada por los recurrentes abarcaba a la totalidad de la ley impugnada por su eventual infracción del principio de seguridad jurídica dada la heterogeneidad de sus contenidos, argumento que será desestimado de acuerdo con la jurisprudencia previa del Tribunal en materia de leyes ómnibus o transversales, no hallándose contravención con el art. 9.3 CE. En cuanto a las impugnaciones específicas: en relación con el art. 7.4 no se aprecia vulneración de la autonomía local, la eventual contradicción con la legislación estatal de costas se salva con un pronunciamiento interpretativo, y se declara inconstitucional y nulo el inciso «sin afectar a la equidistribución y cesión" por incompatibilidad en lo dispuesto en la legislación estatal, concretamente en el art. 7.1 TRLSRU, regulador de las actuaciones de transformación urbanística y las actuaciones edificatorias; también por inconstitucionalidad mediata el apartado nueve del art. 22 de la Ley 10/2018 se considera contrario al orden constitucional de distribución de competencias, siendo declarados inconstitucionales y nulos los incisos «ni ambientales», "y, de acuerdo con la normativa ambiental básica, no establezcan el marco para la futura autorización de proyectos legalmente sometidos a 
evaluación de impacto ambiental» $\mathrm{y}$ «sin producirse una transformación que suponga efectos significativos para el medio ambiente». También son objeto de pronunciamiento interpretativo el art. 23.4 y la disposición adicional primera. Las demás tachas de inconstitucionalidad quedan desestimadas.

La STC 176/2019, de 16 de diciembre, inadmite el recurso interpuesto por el Consejo de Gobierno de La Rioja en relación con diversos preceptos de la Ley del Parlamento de La Rioja 6/2018, de 26 de noviembre, de protección de los animales, por falta de legitimación activa de su promotor, al no contemplar la LOTC tal posibilidad. Se formulan tres votos particulares, cuyos firmantes son los magistrados D. Juan Antonio Xiol, D. Pedro González-Trevijano —al que se adhiere D. Ricardo Enríquez-, y Dña. M. ${ }^{a}$ Luisa Balaguer; en todos, frente a la opinión de la mayoría, se argumenta que la Constitución señala de forma indiferenciada la posibilidad de que interpongan recursos de inconstitucionalidad los órganos ejecutivos o las Asambleas de las CC. AA., lo que les lleva a interpretar que la legitimación existiría también, como en el caso controvertido, para impugnar una disposición con rango de ley de la propia comunidad.

La STC 178/2019, de 16 de diciembre, resuelve el recurso interpuesto por el presidente del Gobierno en relación con diversos preceptos de la Ley Foral 23/2018, de 19 de noviembre, de las policías de Navarra. La controversia es de carácter competencial, en la medida en que se alega que los preceptos impugnados vulneran los arts. 149.1.18 y 149.1.29 CE, que atribuyen al Estado competencia exclusiva en materia de «bases del régimen estatutario de los funcionarios públicos» y de "seguridad pública», tal como dichas competencias se han plasmado en la Ley 7/1985, de 2 de abril, reguladora de las bases del régimen local (LBRL), y en la Ley Orgánica 2/1986, de 13 de marzo, de fuerzas y cuerpos de seguridad del Estado (LOFCS), respectivamente. De las impugnaciones formuladas se estiman la relativa al art. 11.7, que pasa a declararse inconstitucional y nulo, y, por las mismas razones, también el inciso «sin perjuicio de lo dispuesto en el artículo 11 párrafo 7 de esta ley foral» del art. 23.3, en cuanto que es corolario del anterior; así como los incisos «teniendo a los efectos anteriores la consideración de agentes de la autoridad» del art. 24.2 y «el órgano competente de cada entidad local determinará motivadamente, en aquellos casos en que el servicio lo requiera, qué unidades o integrantes de la policía local podrán ejercer sus funciones sin vestir el uniforme» del art. 27.1.

B) Las sentencias dictadas en cuestiones de inconstitucionalidad han sido diez.

La STC 106/2019, de 19 de septiembre, resuelve la cuestión planteada por la Sección Primera de la Sala de lo Contencioso-Administrativo del 
Tribunal Superior de Justicia de las Illes Balears en relación con la disposición transitoria segunda del Decreto Ley del Gobierno de Illes Balears 1/2017, de 13 de enero, de modificación de la Ley 20/2006, de 15 de diciembre, municipal y de régimen local de las Illes Balears, y de la Ley 3/2007, de 27 de marzo, de la función pública de la Comunidad Autónoma de las Illes Balears, y de medidas en materia de coordinación de las policías locales de las Illes Balears, y con el art. 41 de la Ley del Parlamento de Illes Balears 4/2013, de 17 de julio, de coordinación de las policías locales de las Illes Balears. El Tribunal constata, tras una lectura sistemática de la normativa básica estatal, que la apelación del precepto a los «funcionarios de carrera» no debe interpretarse como una reserva exclusiva de determinadas funciones a los funcionarios de carrera, con exclusión de los interinos, sino como sinónimo de funcionario público, lo que también incluiría a los interinos. En consecuencia, la sentencia considera compatibles las disposiciones autonómicas cuestionadas con la norma estatal de contraste, desestimando la cuestión.

La STC 117/2019, de 16 de octubre, resuelve la cuestión planteada por el Juzgado de lo Contencioso-Administrativo núm. 2 de Ourense respecto del art. 110.2 de la Ley 8/2008, de 10 de julio, de salud de Galicia. La argumentación del Tribunal se condensa en la consideración de que el precepto cuestionado «no resulta contrario a la regulación estatal prevista en el art. 66.3 del Estatuto Marco, debiendo interpretarse que el precepto estatal se refiere específicamente al personal estatutario excedente por prestar servicios en el sector público, mientras que la norma autonómica regula otros supuestos de cambio de régimen de personal que no conllevan la situación de excedencia» (FJ 4).

La STC 118/2019, de 16 de octubre, resuelve la cuestión planteada por el Juzgado de lo Social núm. 26 de Barcelona, en relación con el art. 52 d) del texto refundido de la Ley del Estatuto de los Trabajadores, aprobado por Real Decreto Legislativo 2/2015, de 23 de octubre. La normativa cuestionada permite el despido por causa de absentismo derivado de enfermedades intermitentes de corta duración, hayan dado o no lugar a la expedición de partes oficiales de baja médica. El órgano judicial considera que tal regulación podría vulnerar los derechos a la integridad física (art. 15 CE), al trabajo (art. $35 \mathrm{CE}$ ) y a la protección de la salud (art. 43.1 CE). La sentencia, que arranca su argumentación afirmando que la norma persigue un interés legítimo no desprovisto de fundamento constitucional como es el de proteger la productividad de la empresa y la eficiencia en el trabajo (que encajaría en el art. $38 \mathrm{CE}$ ), descarta cualquier lesión del art. $15 \mathrm{CE}$ al considerar que no genera «un peligro grave y cierto para la salud del afectado» por la medida empresarial. Tampoco aprecia vulneración del art. 43.1 CE, subrayando que la normativa no incide en el régimen de acceso y contenido de la asistencia sanitaria de los 
trabajadores. Finalmente, el Tribunal entiende que la limitación al derecho al trabajo (art. $35 \mathrm{CE}$ ), efectivamente producida, queda justificada por el interés fundamental señalado y resulta equilibrada al haber previsto la normativa diversas excepciones, como la relativa a excluir del cómputo las inasistencias por baja médica durante más de veinte días consecutivos o las derivadas de enfermedad grave. En consecuencia, la cuestión es desestimada.

Se formulan a la sentencia tres votos particulares. El primero lo emite el Sr. Valdés Dal-Ré, adhiriéndose el Sr. Conde-Pumpido. En él se critica que el Tribunal haya omitido el juicio de constitucionalidad sobre el supuesto legal verdaderamente relevante, es decir, aquel que permite despedir al trabajador aunque sus inasistencias continuadas resulten justificadas médicamente. Poniendo el foco en él, el voto particular entiende que tal medida extintiva carece de la «justa causa» que, según doctrina consolidada del Tribunal, exige el art. $35 \mathrm{CE}$, pues supone disuadir al trabajador del derecho al cuidado de su salud. El segundo voto particular, emitido por la Sra. Balaguer Callejón, considera evidente la lesión de los arts. 15 y 43.1 CE, al forzar a los trabajadores a prescindir del cuidado de su salud para no faltar al trabajo, y afirma que la norma incurre también en discriminación indirecta por razón de sexo, en la medida en que las mujeres suelen presentar mayores episodios de incapacidad temporal, debido a las exigencias física de su doble jornada (la familiar, en que suelen asumir las mayores cargas, y la laboral). Finalmente, el Sr. Xiol Ríos formula voto particular expresando su acuerdo con los dos votos anteriores.

La STC 126/2019, de 31 de octubre, resuelve la cuestión planteada por el Juzgado de lo Contencioso-Administrativo núm. 32 de Madrid, respecto de los arts. 107 y 108 del texto refundido de la Ley Reguladora de las Haciendas Locales, aprobado por el Real Decreto Legislativo 2/2004, de 5 de marzo. Esta sentencia sigue la línea de sentencias precedentes relativas a la inconstitucionalidad del impuesto sobre el incremento de valor de los terrenos de naturaleza urbana. En esta ocasión se declara inconstitucional el art. 107.4 en los casos en los que la cuota a pagar sea superior al incremento patrimonial obtenido por el contribuyente.

La STC 134/2019, de 13 de noviembre, resuelve la cuestión planteada por la Sección Primera de la Sala de lo Contencioso-Administrativo del Tribunal Superior de Justicia de Extremadura, respecto del art. 11.3.1 b), párrafo segundo, de la Ley 15/2001, de 14 de diciembre, del suelo y ordenación territorial de Extremadura, en la redacción dada por la Ley 9/2011, de 29 de marzo, y la disposición adicional única de esta última ley. Considera el Tribunal que cuando en el art. 11 de la Ley 15/2001, rubricado «Suelo no urbanizable», se introduce una regla especial para los terrenos incluidos en la 
Red Natura 2000 con el fin de que puedan ser objeto de transformación urbanística, se contraviene lo dispuesto en el art. 12.2 a) TRLS 2008, en conexión con el art. 13.4 del mismo texto legal y con infracción, por tanto, de los arts. 149.1.1 y 23 CE. En consecuencia, procede a declarar su inconstitucionalidad y nulidad. Por lo que respecta a la disposición adicional única, se debe dilucidar, si, como sostiene el órgano a quo, se trataría de una ley singular prevista para un caso específico, cuya intención sería la de eludir la ejecución de su sentencia de 9 de marzo de 2011. Concluyendo el Tribunal que no puede entrar a valorar las intenciones del legislador autonómico, que en todo caso los actos de homologación serían ilegítimos si fuesen resultado de la aplicación de preceptos previamente declarados como inconstitucionales, y que, por tanto, no advierte incompatibilidad de la disposición analizada con los arts. 24.1, 117 y $118 \mathrm{CE}$. Formula un voto particular el magistrado don Ricardo Enríquez, quien se separa de la sentencia mayoritaria cuando sostiene que la inclusión de un terreno en la Red Natura 2000 impide cualquier transformación urbanística.

La STC 152/2019, de 25 de noviembre, resuelve la cuestión planteada por la Sección Primera de la Sala de lo Contencioso-Administrativo del Tribunal Superior de Justicia de Extremadura, respecto del art. 11.3.1 b), párrafo segundo, de la Ley 15/2001, de 14 de diciembre, del suelo y ordenación territorial de Extremadura, en la redacción dada por la Ley 9/2011, de 29 de marzo, y de la disposición adicional única de esta última ley. Tal normativa ya había sido declarada inconstitucional por la Sentencia 134/2019, por lo que la cuestión pierde su objeto y queda extinguida. Por otro lado, y en relación con la disposición adicional única de la propia Ley 9/2011, a la que también se extiende la cuestión, el Tribunal recuerda que la Sentencia 134/2019 desestimó su inconstitucionalidad, por lo que remite a ella.

La STC 153/2019, de 25 de noviembre, resuelve la cuestión planteada por el Juzgado de lo Contencioso-Administrativo núm. 2 de Zaragoza en relación con diversos preceptos del texto refundido de la Ley Reguladora de las Haciendas Locales, aprobado por el Real Decreto Legislativo 2/2004, de 5 de marzo. Esta cuestión ya fue resuelta en la STC 126/2019, en la que se declaró la inconstitucionalidad del art. 107.4 TRLHL por vulnerar el principio de capacidad económica y la prohibición de confiscatoriedad, consagrados en el art. 31.1 CE, en aquellos supuestos en los que la cuota a pagar es superior al incremento patrimonial obtenido por el contribuyente. En consecuencia, el Tribunal declara la pérdida sobrevenida del objeto.

La STC 157/2019, de 28 de noviembre, resuelve la cuestión planteada por la Sección Segunda de la Sala de lo Contencioso-Administrativo del Tribunal Superior de Justicia de Canarias respecto del art. 21.2 de la Ley 
4/1999, de 15 de marzo, de patrimonio histórico de Canarias. La cuestión es estimada al entender que la ley invade las competencias estatales al imponer al interesado una carga adicional en el procedimiento administrativo, a pesar de que, como viene declarando el Tribunal, los procedimientos administrativos de las CC. AA. deben respetar en todo caso las reglas del procedimiento administrativo común fijadas por el Estado ex art. 149.1.18 CE.

La STC 160/2019, de 12 de diciembre, resuelve la cuestión planteada por la Sección Segunda de la Sala de lo Contencioso-Administrativo del Tribunal Superior de Justicia de Madrid en relación con el art. 39.4 de la Ley 17/1997, de 4 de julio, de espectáculos públicos y actividades recreativas de la Comunidad de Madrid, en la redacción dada por el art. 13.3 de la Ley 10/2009, de 23 de diciembre, de medidas fiscales y administrativas. El Tribunal, al abordar el análisis de la constitucionalidad del art. 39.4 de la Ley 17/1997 desde la perspectiva del art. 25.1 CE, concluye que la aplicación de la jurisprudencia constitucional previa en la materia determina que debe declararse la inconstitucionalidad del inciso «y demás normativa de la Comunidad de Madrid» del art. 39.4 de la Ley 17/1997, en la redacción dada por la Ley 10/2009, de 23 de diciembre, por entenderse vulnerado el principio de legalidad exigido en la tipificación sancionadora, al permitir la colaboración reglamentaria sin previamente haber definido los elementos esenciales de la conducta antijurídica en la ley que efectúa la remisión.

La STC 177/2019, de 16 de diciembre, resuelve la cuestión planteada por la Sala de lo Social del Tribunal Superior de Justicia de Cataluña, respecto de la disposición adicional decimotercera de la Ley del Parlamento de Cataluña 5/2012, de 20 de marzo, de medidas fiscales, financieras y administrativas y de creación del impuesto sobre estancias en establecimientos turísticos. La norma cuestionada establecía la jubilación forzosa del personal laboral al servicio del Instituto Catalán de la Salud al cumplir los 65 ańos. El Tribunal declara inconstitucional el precepto por considerar que modifica un aspecto medular de la regulación laboral general como es la extinción del contrato de trabajo, invadiendo la competencia exclusiva del Estado en materia de legislación laboral (art. 149.1.7 CE).

\section{C) Dos han sido los conflictos positivos de competencias.}

La STC 109/2019, de 1 de octubre, resuelve el conflicto planteado por el Gobierno de la Generalitat de Cataluña en relación con los arts. 4 y 7 del Real Decreto 1058/2015, de 20 de noviembre, por el que se regulan las características generales de las pruebas de la evaluación final de educación primaria establecidas en la Ley Orgánica 2/2006, de 3 de mayo, de Educación. El Gobierno 
autonómico considera que la normativa excede la competencia básica que sobre educación posee el Estado (art. 149.1.30), algo que el Tribunal rechaza en lo relativo a la configuración general de las pruebas (art. 4 del real decreto), dado que se limita a fijar unos criterios homogéneos mínimos, dejando margen a las comunidades autónomas para concretar sus características y contenido final. A distinta conclusión llega la sentencia en relación con el procedimiento estipulado para la adopción de medidas que adapten la realización de las pruebas a personas con necesidades específicas (art. 7.4 del real decreto), al entenderlo como una previsión instrumental que cae dentro de la competencia autonómica. Igualmente, se declara inconstitucional el art. 7.5 del real decreto, que contempla la confección por el Ministerio de los cuestionarios de contextualización socioeconómica a realizar conjuntamente con las pruebas finales, por entender que la competencia básica estatal solo permite el establecimiento de unos mínimos comunes a estos, no su uniformidad absoluta.

La STC 114/2019, de 16 de octubre, resuelve el conflicto planteado por el Gobierno de la Generalitat de Cataluña en relación con diversos preceptos del Real Decreto 310/2016, de 29 de julio, por el que se regulan las evaluaciones finales de educación secundaria obligatoria y de bachillerato. El Tribunal recuerda su doctrina establecida en la Sentencia 14/2018 en relación con las pruebas finales de evaluación contempladas en la LOMCE en las etapas de ESO y Bachillerato, que subraya que la competencia estatal sobre regulación de las condiciones de obtención, expedición y homologación de títulos oficiales (art. 149.1.30 CE), aplicable a las pruebas controvertidas en tanto decisivas para la obtención de los respectivos títulos, reserva al Estado toda la función normativa en relación con ellas. Remitiéndose, pues, a la citada doctrina, el Tribunal desestima la impugnación de los arts. 2, 4, 7, 12 y 17, disposición adicional segunda y disposición final quinta del real decreto. La sentencia declara inconstitucionales, sin embargo, las previsiones del texto sobre los cuestionarios de contextualización socioeconómica (arts. 2.1, 2.3, 5.2, 8.3 y disposición final quinta), así como el procedimiento de adaptación de las condiciones de realización de las pruebas a los alumnos con necesidades específicas (art. 8.2), por entender en ambos casos, al igual que hiciera en la Sentencia 109/2019, que caen en el ámbito de la competencia autonómica de ejecución.

D) Se ha presentado una impugnación de disposiciones autonómicas.

La STC 111/2019, de 2 de octubre, resuelve la impugnación formulada por el Gobierno de la nación en relación con la Resolución del Parlamento de 
Cataluña 298/XII, de 7 de marzo de 2019, de creación de la Comisión de Investigación sobre la Monarquía. La sentencia concluye que el Parlamento de Cataluña ha hecho uso de «una potestad estatutaria (art. 59.6 EAC) en un sentido que no es conforme a la Constitución, pues ninguna competencia ostenta la Generalitat —o cualquier otra comunidad autónoma- para "disponer cosa alguna sobre órganos [...] de las instituciones generales del Estado", actuación que incurriría, por tanto, en "incompetencia manifiesta"». A su juicio, al ordenar una investigación genérica de la familia real, «afectaría directamente a la Corona misma, tanto en su dimensión institucional, de la que la propia familia real es indisociable (art. 65.1 CE), como en su condición estricta de órgano constitucional (la jefatura del Estado), vertientes, una y otra, que se integran y unifican en la persona del rey de Espańa, titular de la Corona (art. 57.1 CE) y por ello jefe del Estado (art. 56.1 CE) en el marco de nuestra monarquía parlamentaria (art. 1.3 CE)» (FJ 4 b).

En cuanto a las alegaciones de carácter sustantivo, el Tribunal trae a colación lo sostenido en la STC 98/2019 y considera que la resolución impugnada contraviene la «inviolabilidad» $\mathrm{y}$ «no sujeción a responsabilidad del Rey» reconocida en el art. 56.3 CE «por no ser posible "el sometimiento a control político, a través de una comisión de investigación, de la persona del Rey, pues en la medida en que constitucionalmente todos sus actos como jefe del Estado han de estar refrendados, el responsable de los mismos será, en todo caso, el órgano refrendante"». De este modo, concluye que la Resolución 298/XII del Parlamento de Cataluña, que ha creado la "comisión de investigación sobre la monarquía»:

[...] es contraria al estatus constitucional del monarca, al que la norma fundamental ha caracterizado como «símbolo de la unidad y permanencia del Estado» y confiado el arbitrio y moderación del funcionamiento regular de las instituciones (art. 56.1 CE), «en orden a asegurarle una posición de neutralidad respecto de la contienda política, posición que le hace acreedor de un respeto institucional cualitativamente distinto al de las demás instituciones del Estado" [STC 98/2019, FJ 4 b) que cita el precedente ATC 213/2006, de 3 de julio, FJ 6]. (FJ 5 c).

E) El número de recursos de amparo ha sido de 55.

Del total de recursos de amparo han sido estimados 48 y 5 , parcialmente estimados, de 42 de ellos se ha fallado la retroacción de actuaciones.

Los actores se distribuyen de la siguiente manera:

- Particulares: 42.

- Cargos representativos: 5 . 
- Ayuntamiento: 1 .

- Asociación: 1.

— Entidades mercantiles: 6, de ellas 4 SL y 2 SA.

La STC 103/2019, de 16 de septiembre, inadmite el recurso al no haber agotado la vía judicial previa.

La STC 104/2019, de 16 de septiembre, inadmite el recurso por extemporáneo y error en su objeto. Formula un voto particular el Sr. Xiol, en el cual seńala el «formalismo enervante» del recurso de amparo y el riesgo al que se enfrenta el demandante de amparo de ser entregado a Tailandia en cumplimiento de la extradición solicitada.

La STC 108/2019, de 30 de septiembre, estima una vulneración del derecho a la igualdad por discriminación por razón de sexo. En el presente caso la recurrente vio conculcado su derecho de acceso a empleo público por encontrarse en situación de baja por maternidad, dado que, según dice el INE (que convocaba el proceso) esto impedía cubrir de modo inmediato la plaza que se había convocado con carácter urgente, por lo que se opta por cubrirla con otra opositora sin ofrecer alternativa viable alguna a la recurrente. Como ya ha señalado el Tribunal en otros casos, para apreciar la discriminación es suficiente la objetividad del perjuicio, sin necesidad de que haya ánimo lesivo, motivo por el cual se indica que las necesidades del servicio no pueden emplearse como justificación habilitante de la discriminación producida.

La STC 120/2019, de 28 de octubre, desestima la invocada vulneración del derecho a la igualdad en la aplicación de la ley al entender el Tribunal que la sentencia impugnada no introduce un cambio interpretativo del órgano judicial sobre la aplicación del art. 29.1 LJCA, y que la desestimación fue debida a las concretas «circunstancias fácticas» que no resultaban equiparables.

La STC 125/2019, de 31 de octubre, resuelve el recurso de amparo que dio lugar al planteamiento de la cuestión interna de inconstitucionalidad que falló en la STC 85/2019 la inconstitucionalidad y nulidad de los incisos «inexistencia del hecho imputado» y "por esta misma causa» del art. 294.1 LOPJ por reputarlos incompatibles con los arts. 14 y $24.2 \mathrm{CE}$. En el fallo, no obstante, se establece la retroacción de las actuaciones, para que de esta forma se determine lo procedente en este caso con respecto a la posible indemnización por el tiempo en prisión provisional ante la posterior absolución. Formula un voto particular discrepante la Sra. Roca, en el que se remite al que formulara a la STC 85/2019.

Las SSTC 130 y 131/2019, ambas de 13 de noviembre, las SSTC 135 a 145, 147 y 151/2019, todas de 25 de noviembre, la STC 154/2019, de 28 de 
noviembre, y las SSTC 162, 163, 164, 165, 166, 167, 168, 169, 170, 171, 173, 174 y 175/2019, todas de 16 de diciembre, aplican las consecuencias de la STC 85/2019 y del posterior recurso de amparo resuelto en la STC 125/2019.

La STC 146/2019, de 25 de noviembre, estima una vulneración de la libertad de expresión en el ámbito laboral al haberse despedido al trabajador por haber trasladado sus quejas sobre la empresa al Ayuntamiento para el cual la empresa prestaba servicios de carácter social. El Tribunal entiende que, dado que no existió exceso al trasladar esas quejas, primaría la libertad de expresión frente a la buena fe contractual.

El derecho de acceso a los cargos públicos es el objeto de la STC 110/2019, de 2 de octubre. En ella el Tribunal reconduce los motivos alegados por los recurrentes (un grupo parlamentario) a la siguiente cuestión: examinar si la mesa de la Cámara se ha extralimitado en el ejercicio de sus funciones, al no trasladar al pleno, previa audiencia de la junta de portavoces, la solicitud de tramitación de la iniciativa por el procedimiento de lectura única, lo que le lleva a afirmar que el «derecho al "procedimiento debido", indudablemente asociado al reconocido en el artículo 23.2 CE, no debe confundirse con un inexistente "derecho" al procedimiento "preferido" (FJ 2 B b), y, a su vez, que "lo decisivo es que la audiencia - de ser relevante para el derecho fundamental invocado - tuvo lugar, sin que el recurso de amparo del artículo 42 LOTC sirva en modo alguno de cauce para discutir sobre infracciones puramente formales, reales o supuestas, de la legalidad parlamentaria» (FJ 2 B). Lo anterior le lleva a concluir que, teniendo en cuenta que el Reglamento de la Cámara atribuye a la mesa la «facultad de proponer al pleno, "oída la junta de portavoces", la tramitación directa y en lectura única de un proyecto o proposición, una vez tomada esta última en consideración, cuando por el órgano de gobierno se aprecie que concurren en el texto de la iniciativa legislativa las condiciones» fijadas, procede rechazar desestimar el recurso.

La STC 115/2019, de 16 de octubre, declara la vulneración del derecho a ejercer las funciones representativas con los requisitos que señalan las leyes (art. 23.2 CE), en conexión con el derecho de los ciudadanos a participar en los asuntos públicos a través de sus representantes, reiterando jurisprudencia anterior sobre supuestos sustancialmente iguales. La mesa del Parlamento catalán ha admitido a trámite una moción que es reiteración de la Resolución 1/XI, declarada inconstitucional. Esta admisión a trámite supone la vulneración del derecho de participación política de los parlamentarios recurrentes porque ejercer sus actividades representativas supondría no acatar lo resuelto por el Tribunal Constitucional. Formula un voto particular concurrente la magistrada Dña. Encarnación Roca. 
En la STC 128/2019, de 31 de octubre, se analiza la admisión a trámite por parte del presidente y la mesa del Parlamento de Cataluña de diversas enmiendas a la Resolución "Restitución de las Instituciones Catalanas», en las que se insiste en la legitimidad del referéndum de independencia del 1 de octubre de 2017. A juicio de los parlamentarios recurrentes ello afectaría a su derecho al ejercicio de las funciones representativas (art. $23 \mathrm{CE}$ ), pues la tramitación de tales enmiendas supondría un incumplimiento del obligado respeto a lo resuelto por el Tribunal Constitucional, lo cual les obligaría a elegir entre no participar en el procedimiento legislativo, desatendiendo sus funciones representativas, o participar en él, infringiendo aquel deber de respeto. El Tribunal constata que las enmiendas en cuestión van frontalmente en contra de lo estipulado en la Sentencia 114/2017 y en el Auto 144/2017, pues insisten en afirmar la soberanía de Cataluña, constituida en un Estado independiente en forma de república en virtud de la legitimidad ofrecida por el referéndum de independencia convocado por la Ley 19/2017. En consecuencia, la participación en el procedimiento legislativo, aunque fuera para votar en contra, supondría "otorgar a la actuación de la cámara una apariencia de legitimidad democrática que no cabe atribuirle sin menoscabar su propia función constitucional». Por ello, el amparo solicitado es estimado, al impedir la iniciativa que los parlamentarios ejerzan legítimamente las funciones representativas propias de su cargo.

La STC 156/2019, de 28 de noviembre, resuelve un recurso de amparo presentado por varios diputados del Grupo Parlamentario Ciutadans del Parlamento de Cataluńa contra los acuerdos y resoluciones de la mesa y del presidente de la Cámara que permitieron la tramitación de la moción subsiguiente a la interpelación al Gobierno sobre la normativa del Parlamento anulada y suspendida por el Tribunal Constitucional. Los diputados recurrentes denunciaron la vulneración del ius in officium propio del cargo de parlamentario, protegido por el art. 23.2 CE, al considerar que los acuerdos y decisiones impugnados incumplieron resoluciones del Tribunal Constitucional, lo que comporta, conforme a la doctrina de las SSTC 46/2018 y $47 / 2018$, dicha vulneración. El recurso se plantea contra los mismos acuerdos parlamentarios y por los mismos motivos que en el recurso de amparo resuelto en la STC 115/2019, por lo que el Tribunal trae a colación lo decidido en esta. En dicha resolución «se apreció que la decisión que adoptaron dichos acuerdos de la mesa de la Cámara constituyó "un manifiesto incumplimiento de su deber de respetar lo resuelto por este Tribunal (arts. 9.1 CE y 87.1 LOTC)" (FJ 7) y que tal incumplimiento de este deber determinaba en ese supuesto la lesión del ius in officium de los parlamentarios recurrentes (FJ 7), por lo que se otorgó el amparo» (STC 156/2019, FJ 2). En consecuencia, concluye que se ha vulnerado el derecho garantizado por el art. 23.2 CE concediendo el amparo. 
Asimismo, se refiere al ejercicio de funciones representativas la STC 159/2019, de 12 de diciembre, que desestima el recurso de amparo promovido por un diputado de la Asamblea de Extremadura contra varios acuerdos de la mesa de la Asamblea, por los que se atribuye al recurrente, tras manifestar su voluntad de dejar de pertenecer al Grupo Parlamentario Popular, la condición de diputado no adscrito y se delimitan las atribuciones y derechos conforme a dicha condición. En primer término, se resuelve la cuestión de admisibilidad suscitada sobre la falta de firmeza al no haberse empleado el recurso de reconsideración. Sobre ello, el Tribunal considera que, al no tratarse de un acto de calificación o admisión a trámite, sino de un acto parlamentario referido al estatus de diputado no adscrito, las vías que resultan de aplicación son las siguientes. Por un lado, el art. 39 del Reglamento de la Asamblea de Extremadura atribuye a la mesa la competencia para resolver las cuestiones planteadas con dicha situación, y, por otro, el art. 19.2 del Reglamento establece que «los diputados tendrán derecho a requerir el amparo de la mesa o del presidente de la cámara en el ejercicio de sus funciones como diputado» (FJ 2). En segundo lugar, la sentencia descarta la alegación invocada por el recurrente en virtud de la cual las eventuales lesiones del derecho garantizado en el art. 23.2 CE pudieran provenir no de los actos de aplicación de la mesa, sino de la norma contenida en el art. 39.2 del Reglamento de la Cámara (FJ 8). Antes de resolver la cuestión de fondo, el Tribunal trae a colación su consolidada doctrina constitucional sobre los derechos del art. $23 \mathrm{CE}$, la exclusión de los derechos de contenido económico del núcleo esencial del ius in officium (STC 36/2014), y las limitaciones del ius in officium por razón del transfuguismo político (STC 151/2017). De este modo, confirma la constitucionalidad del art. 39.5 del Reglamento de la Asamblea de Extremadura con el art. $23 \mathrm{CE}$ al considerar que se trata de «una disposición reglamentaria que cierra el paso a una excesiva representación del diputado no adscrito». Una vez precisado que «no es constitucionalmente ilegítimo el trato diferente entre representantes políticos cuando se orienta a impedir una posición preponderante de unos sobre otros» (FJ 10) y que ello «neutraliza la desigualdad en el ejercicio de la función representativa que llevaría aparejada la sobrerrepresentación del diputado no adscrito", la sentencia concluye que varios de los acuerdos impugnados niegan al recurrente la posibilidad de presentar propuestas de pronunciamiento en pleno, privándole de facultades que, además de ser inherentes a la función representativa, aparecen atribuidas al diputado no adscrito por el art.39.5 del Reglamento. Por ello, estima parcialmente el recurso, si bien no procede a adoptar medidas de restablecimiento del derecho vulnerado porque los acuerdos fueron aprobados durante una legislatura ya finalizada. Formula un voto particular el Sr. Ollero, quien discrepa sobre el papel asignado al diputado no adscrito. 
En el recurso que da lugar a la STC 155/2019, de 28 de noviembre, fueron numerosos los derechos invocados: libertad ideológica y de expresión, participación política, a la defensa, juez predeterminado por la ley e imparcial, a la presunción de inocencia y a la legalidad penal, y derecho a la vida privada. El Tribunal declara la inadmisión parcial del recurso al no haberse alegado previamente la lesión de los derechos a la libertad ideológica y de expresión, del derecho al recurso y del derecho a la presunción de inocencia y como prematura la alegada vulneración del derecho al juez predeterminado por la ley. Con respecto a la adopción y prórroga de la prisión provisional, recuerda el Tribunal que solo le corresponde ejercer un control externo sobre si la resolución judicial es proporcionada, razonada y fundada en derecho, extremos que considera acordes no solo a su propia jurisprudencia sino también a la del TEDH, lo que le lleva a la desestimación del amparo solicitado. Formulan un voto particular discrepante los magistrados Sres. Valdes, junto con la Sra. Balaguer, y uno concurrente el Sr. Martínez-Vares.

Los recursos de amparo que abordan el derecho a la tutela judicial efectiva son los siguientes:

a) Acceso a la jurisdicción: STC 112/2019, de 3 de octubre, en la cual el Tribunal cambia su doctrina en relación con el deber de interponer el incidente de nulidad de actuaciones. El órgano judicial realiza una interpretación de la normativa procesal formalista y desproporcionada porque no analizó si la falta de agotamiento de la vía administrativa se debía a la actuación de la propia Administración (que no habría cumplido con indicar cómo podría recurrirse la resolución). El Tribunal aprovecha esta sentencia para modificar su doctrina en relación con el deber de interponer el incidente de nulidad de actuaciones para entender agotada la vía judicial previa al recurso de amparo, indicando que de la regulación de este recurso no puede inferirse la obligatoriedad de presentarlo en los casos en los que el recurso interpuesto contra la resolución que se considera vulneradora de derechos fundamentales se inadmita por motivos procesales no imputables a la falta de diligencia de la parte (como era el caso, en el que se había inadmitido el recurso de casación por falta de interés casacional), por tanto, la falta del incidente no supone que el recuro de amparo sea prematuro en estos casos. Ahora bien, si en estos casos se interpone el incidente de nulidad de actuaciones, tampoco será considerado como un recurso "manifiestamente improcedente», pues es un mecanismo idóneo para la defensa de los derechos fundamentales, por lo que no convertirá al recurso de amparo en extemporáneo. 
La STC 121/2019, de 28 de octubre, estima el recurso por denegar la legitimación de la federación recurrente al no reconocerle interés legítimo para actuar en defensa de los intereses de sus asociados. Asimismo, se consideran también afectados el principio de contradicción al no haber tenido posibilidad de hacer alegaciones en ningún momento del proceso en relación con la causa de inadmisión por falta de legitimación, el principio de justicia rogada por haber apreciado la Sala falta de legitimación de oficio, e incongruencia omisiva al no pronunciarse sobre la pretensión principal de la demanda (cuestiones que el Tribunal no entrará a valorar al estimar el primer motivo de impugnación). Entrando en el fondo, considera el Tribunal que la recurrente es una federación de asociaciones de escuelas infantiles que defiende y representa los intereses económicos y profesionales de los centros de educación infantil a ella asociados. Debe tenerse en cuenta que en la vía judicial impugnó la inactividad de la Junta de Andalucía en el cumplimiento del acuerdo suscrito por esta y dicha federación, además de otras entidades, puesto que tal inactividad tenía un efecto perjudicial sobre sus asociadas de manera mediata o inmediata, mientras que, por el contrario, su cumplimiento repercutiría de manera positiva sobre estas. Existiendo, por consiguiente, evidentes vínculos económicos y profesionales entre las escuelas asociadas y la federación, y la pretensión ejercitada en el contencioso-administrativo por esta última en beneficio de las primeras. Lo que lleva a concluir la evidencia de una relación directa entre los fines de la federación y los concretos motivos en que se fundamentaba el recurso por inactividad de la Consejería de Educación de la Junta de Andalucía, siendo así la sentencia impugnada lesiva del derecho de la recurrente a la tutela judicial efectiva (art. 24.1 CE) al incurrir en una restricción rigorista y desproporcionada del acceso a la jurisdicción.

b) Acceso a los recursos: STC 101/2019, de 16 de septiembre, en la que se analiza este derecho en relación con el derecho a la asistencia jurídica gratuita, la cual se le había denegado al recurrir porque no la había solicitado en primera instancia y no habían cambiado las condiciones económicas del recurrente. Supuesto sustancialmente igual al resuelto por la STC 90/2015, por lo que se da por reproducida su doctrina. En la STC 119/2019, de 28 de octubre, la estimación del recurso se basa en que la denegación de la asistencia jurídica gratuita cercenó al recurrente la posibilidad de un pronunciamiento por el tribunal al que correspondía en última instancia adoptar una decisión sobre la admisión y, en su caso, la estimación o desestimación del recurso. 
La STC 124/2019, de 28 de octubre, en la cual la argumentación contenida en la sentencia impugnada, según la cual el cómputo del plazo para interponer el recurso de apelación opera independientemente de que el órgano judicial lleve o no a efecto la prestación que le incumbe (entrega de las copias de los soportes de grabación de las sesiones), se estima irrazonable, lo que lleva al Tribunal a estimar el amparo planteado.

c) Actos de comunicación procesal: en las SSTC 102/2019, de 16 de septiembre, 122/2019, de 28 de octubre, 129/2019, de 11 de noviembre, y 150/2019, de 25 de noviembre, se reitera la doctrina de las SSTC 6 y 47/2019, en torno al límite a la primera comunicación electrónica; la última de las sentencias citadas cuenta con un voto particular del Sr. Montoya por considerar que tenía que haberse estimado, asimismo, la vulneración de los derechos a no padecer indefensión y a la utilización de la prueba pertinente.

La STC 123/2019, de 28 de octubre, incide en la obligación de agotar todos los medios de comunicación procesal de carácter personal antes de recurrir a los edictos.

d) Tutela judicial efectiva: STC 107/2019, de 30 de septiembre. Analiza el rechazo por parte del Juzgado de lo Contencioso-Administrativo a valorar las escrituras de compraventa aportadas por el particular para acreditar minusvalía en la transmisión de un bien inmueble, y ello a efectos del impuesto sobre plusvalía. Se aprecia la infracción del derecho a la valoración de la prueba conforme a las reglas de la sana crítica (art. 24.1 CE), al haber eludido el juzgado el estudio de la escritura presentada en virtud de argumento irrazonable, pues apoyó su rechazo en la remisión a otra sentencia en la que se abordaba un supuesto muy distinto: el de un particular que no aportó tal escritura sino un mero comentario general sobre la evolución del mercado inmobiliario.

e) Resolución fundada en derecho: STC 148/2019, de 25 de noviembre, en la que se analiza la posible vulneración del derecho a una resolución fundada en derecho (art. 24.1 CE) provocada por la decisión del Juzgado de 1. a Instancia de excluir como postor al marido de la recurrente en amparo en el seno de un procedimiento de subasta para la ejecución de sentencia de división de cosa en común, y ello por considerar que su nexo matrimonial negaba su condición de tercero. El Tribunal estima el amparo, al constatar que la conclusión del juzgado se alcanza sin argumentación ni fundamentación jurídica alguna. El hecho de que el marido de la recurrente no fuera propietario de la 
vivienda en cuestión, ni hubiera por ello solicitado en demanda su división, ni hubiera sido tampoco demandado, son circunstancias de relieve que bien merecían, según la sentencia, una explicación de por qué se le niega la necesaria condición de tercero.

f) Derecho a un proceso con todas las garantías y a la presunción de inocencia: STC 149/2019, de 25 de noviembre, en la que se analiza la condena en segunda instancia al recurrente, que había sido absuelto en primera, tras una reconsideración global de los hechos a partir de pruebas documentales y personales sin haber celebrado la debida vista pública que permitiera la defensa contradictoria del acusado, reiterando su consolidada jurisprudencia sobre las exigencias que debe reunir una condena penal en segunda instancia para respetar el art. 24.2 CE, condensada en la Sentencia 88/2013, el Tribunal afirma la vulneración del derecho a un proceso con todas las garantías y del derecho a la presunción de inocencia del recurrente, al haberse omitido las debidas garantías de publicidad, inmediación y contradicción.

Por igual motivo, en este caso con base en un delito de prevaricación administrativa, se estima el recurso presentado en la STC 172/2019, de 16 de diciembre.

Las resoluciones recurridas se distribuyen de la siguiente manera:

\begin{tabular}{lccc}
\hline \multicolumn{1}{c}{ Órgano } & Sentencia & Auto & Providencia \\
\hline Tribunal Supremo & 1 & 5 & 5 \\
Audiencia Nacional & 19 & & \\
Juzgado Central de lo Contencioso-Administrativo & 2 & & \\
Tribunal Superior de Justicia & 4 & & \\
Audiencia Provincial & 3 & & \\
Juzgado de 1.a Instancia & & 4 & \\
Juzgado de lo Contencioso-Administrativo & 1 & & \\
Juzgado de lo Social & & 1 & 1 \\
Juzgado de lo Mercantil & & 1 & \\
Juzgado de Vigilancia Penitenciaria & & 1 & \\
\hline
\end{tabular}

Resolución de mesa del Parlamento: 5.

Los magistrados que han formulado votos particulares (contando alguno con la adhesión de otros magistrados) han sido los siguientes: 


\begin{tabular}{lc}
\hline \multicolumn{1}{c}{ Magistrado } & N. ${ }^{\circ}$ votos particulares \\
\hline Sra. Balaguer Callejón & 3 \\
Sr. Enríquez Sánchez & 3 \\
Sr. González-Trevijano Sánchez & 1 \\
Sr. Martínez-Vares García & 1 \\
Sr. Montoya Melgar & 2 \\
Sr. Ollero Tassara & 2 \\
Sr. Narváez Rodríguez & 1 \\
Sra. Roca Trías & 1 \\
Sr. Valdés Dal-Ré & 3 \\
Sr. Xiol Ríos & 4 \\
\hline
\end{tabular}

Gráfico 1. RELACIÓN DE SENTENCIAS

DEL TRIBUNAL CONSTITUCIONAL. TERCER CUATRIMESTRE DE 2019 Por procedimientos

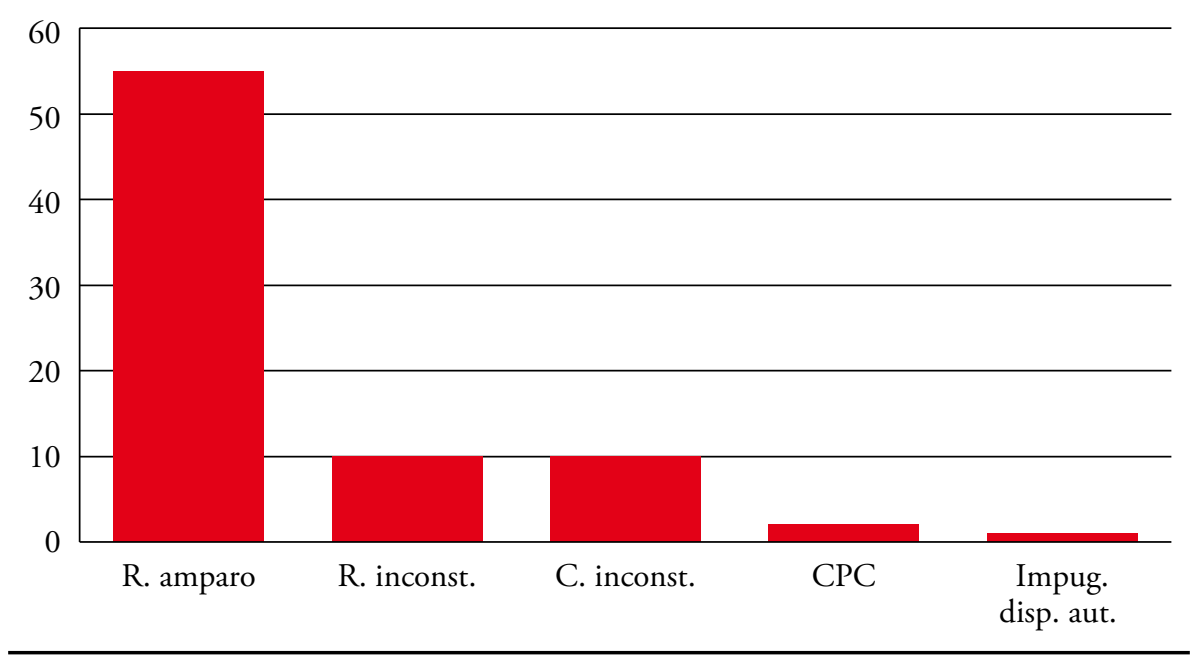



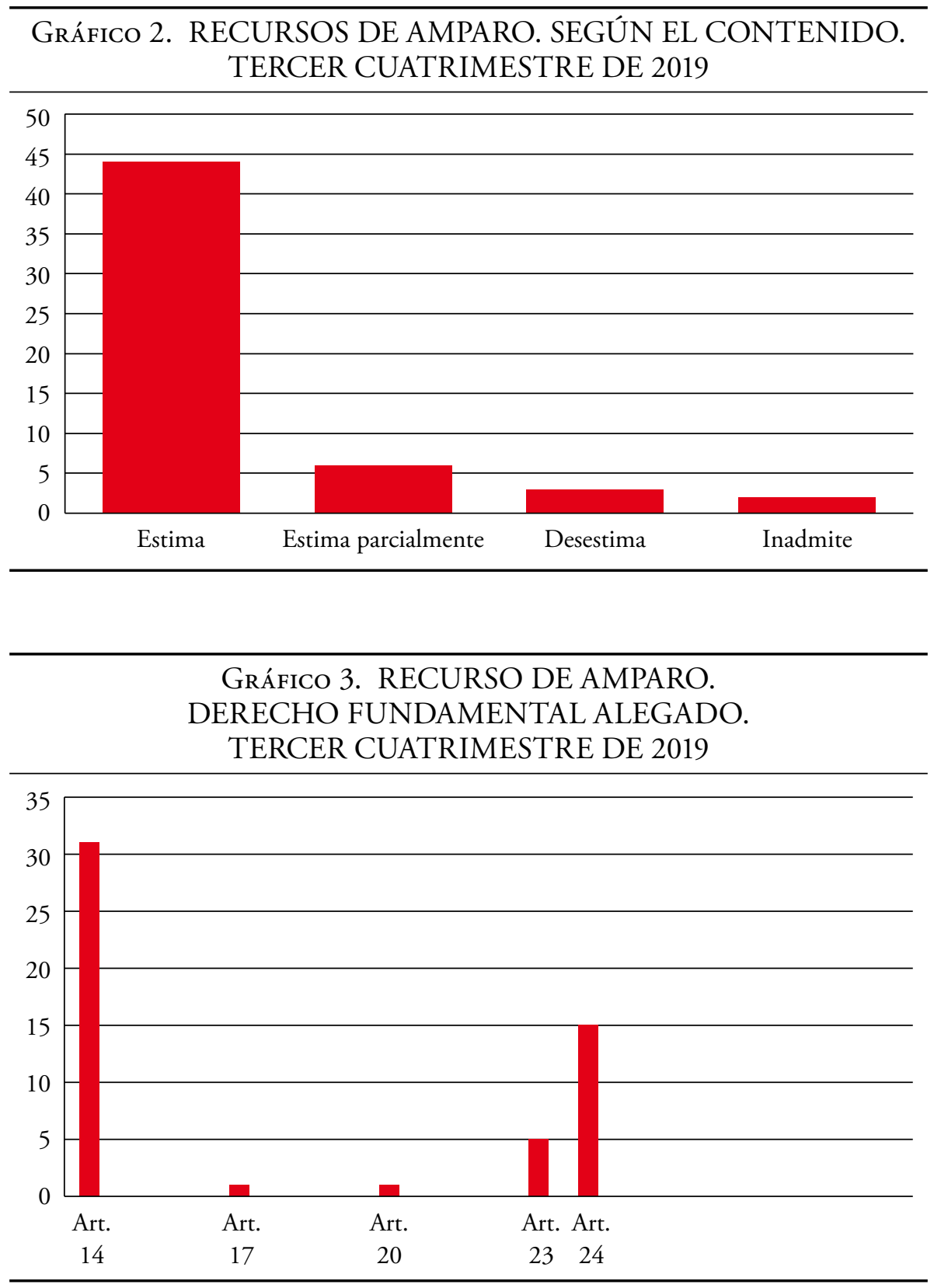
GrÁFICO 4. RECURSOS DE AMPARO. ÓRGANO JUDICIAL QUE DICTA LA RESOLUCIÓN RECURRIDA. TERCER CUATRIMESTRE DE 2019

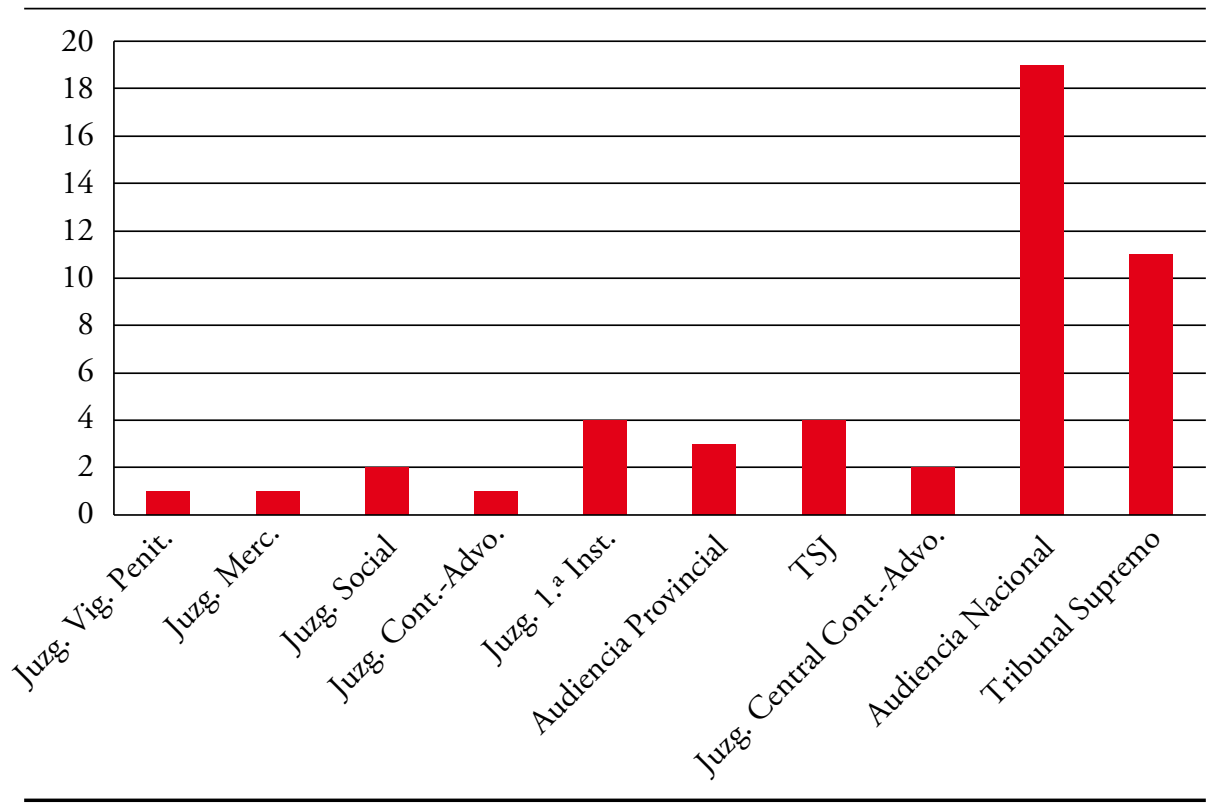

GrÁFICO 5. RECURSOS DE AMPARO.

TIPO DE RESOLUCIÓN RECURRIDA.

TERCER CUATRIMESTRE DE 2019

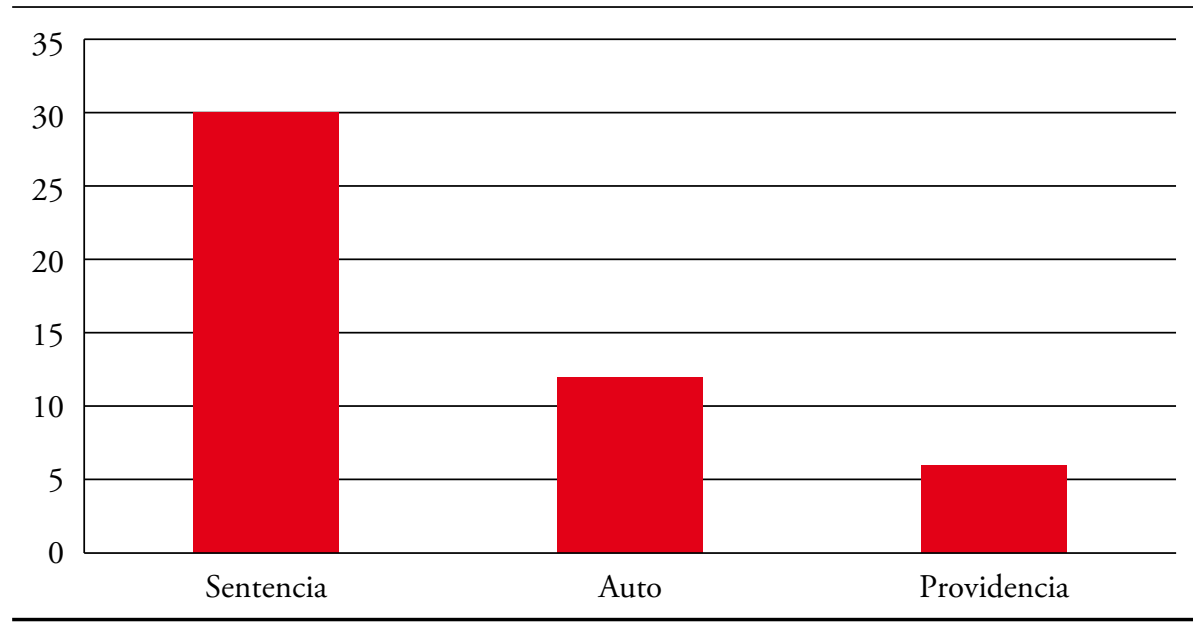




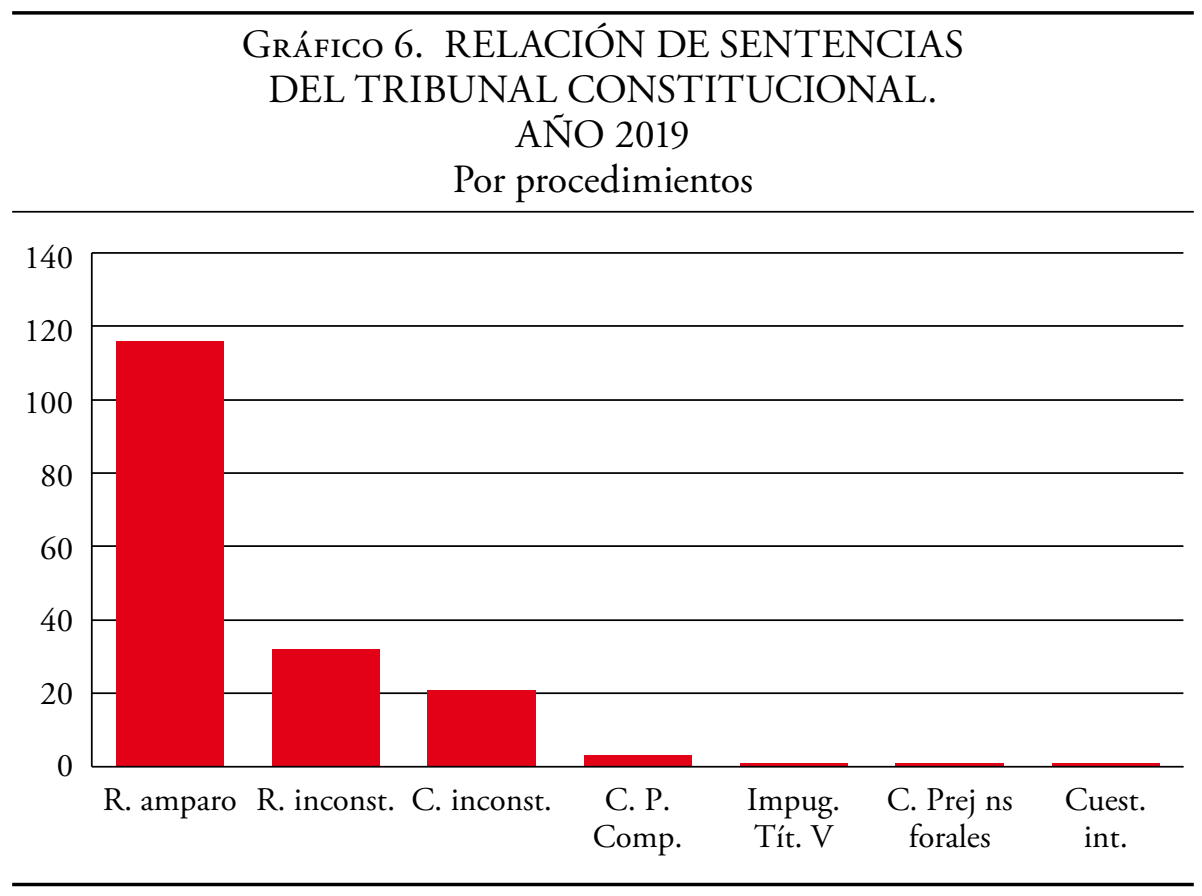

GRÁfICo 7. RECURSOS DE AMPARO. SEGÚN EL CONTENIDO. AÑO 2019

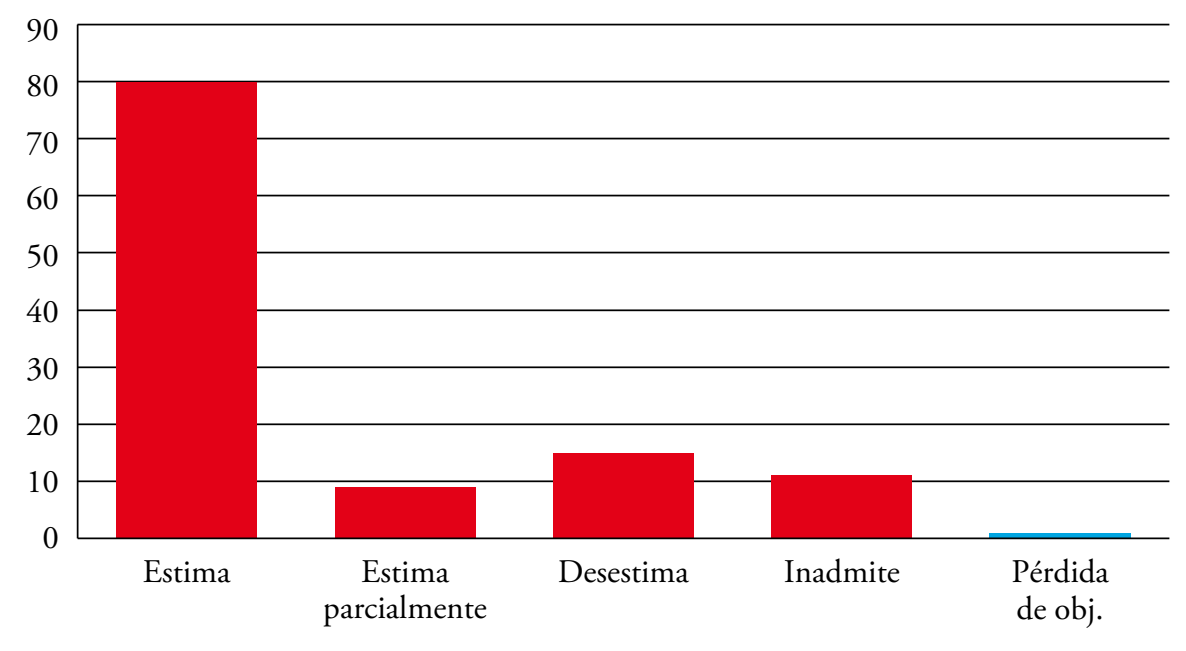


GRÁFICO 8. RECURSO DE AMPARO.

DERECHO FUNDAMENTAL ALEGADO.

AÑO 2019

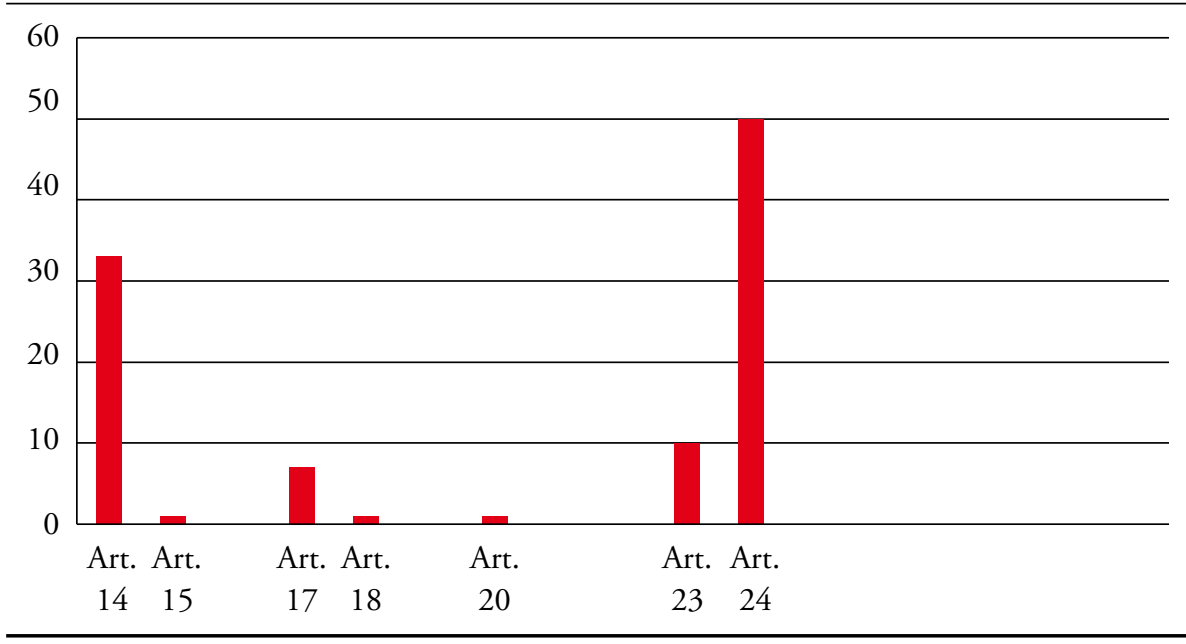

GrÁFICO 9. RECURSOS DE AMPARO. ÓRGANO

QUE DICTA LA RESOLUCIÓN RECURRIDA.

AÑO 2019

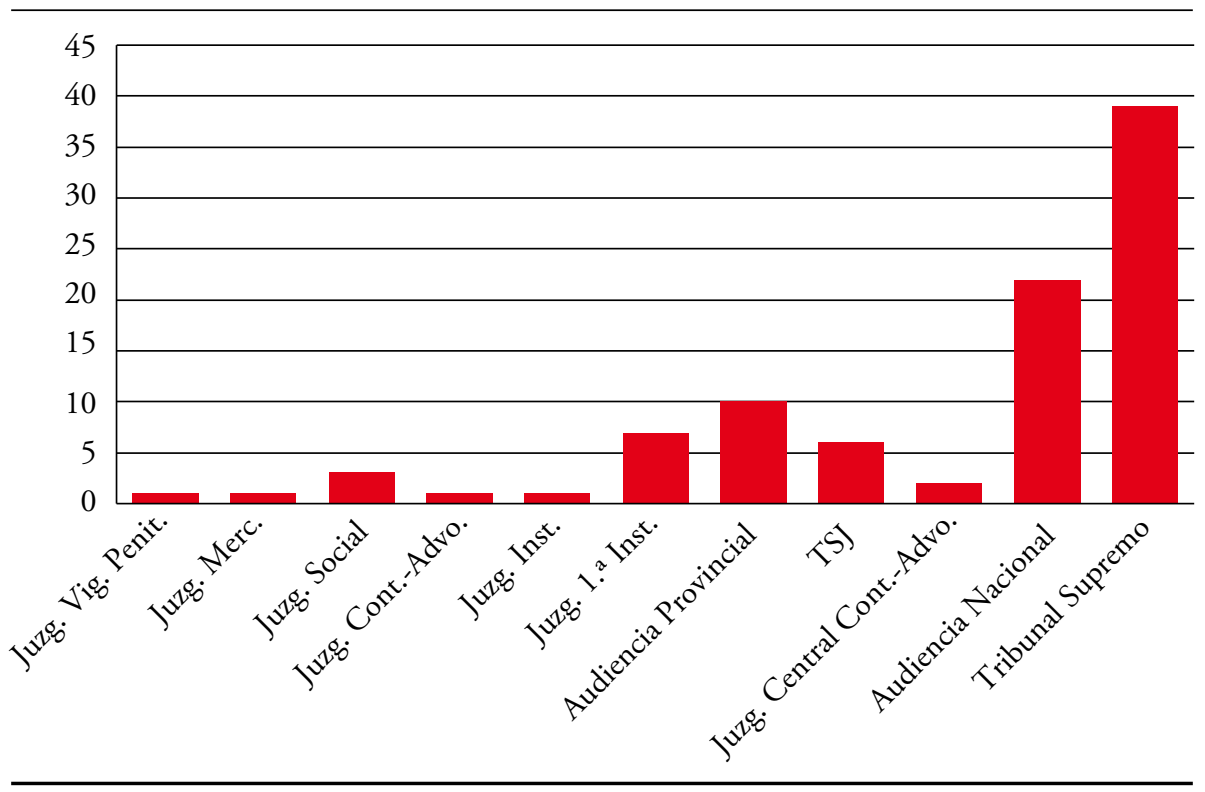


GrÁFICO 10. RECURSOS DE AMPARO.

TIPO DE RESOLUCIÓN RECURRIDA. AÑO 2019

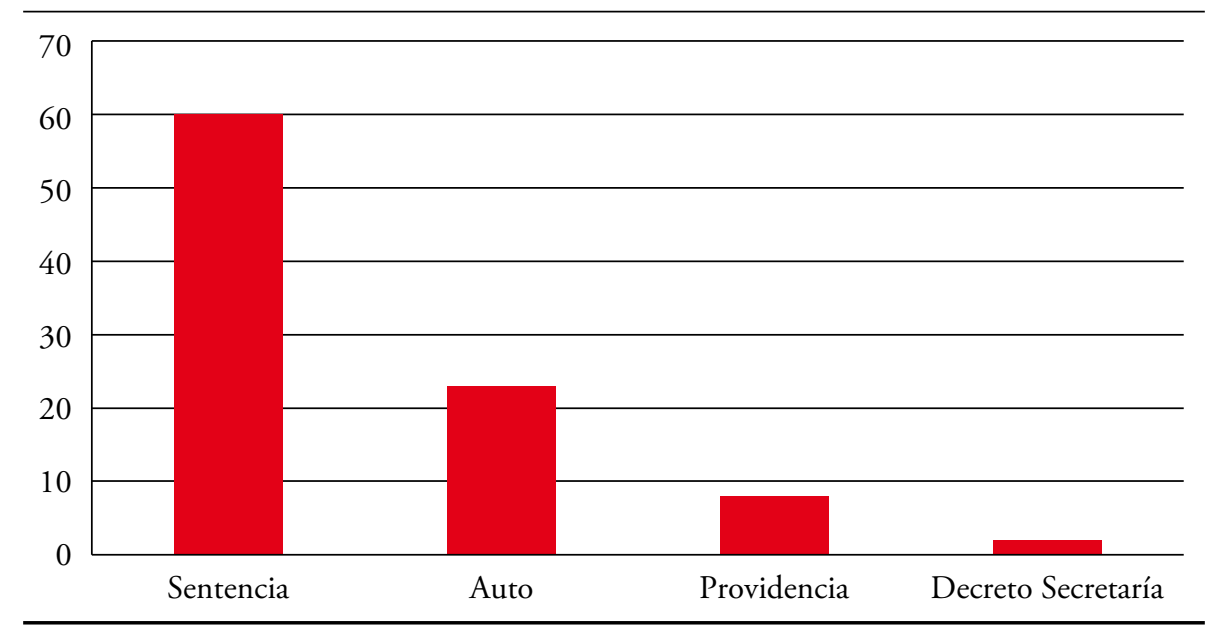

